\section{Comparison of actions of disodium cromoglycate and ketotifen on exercise-induced bronchoconstriction in childhood asthma}

Ketotifen (Zaditen), a benzocycloheptathiophene derivative, is a new oral agent for treating asthma, with action similar in some respects to that of sodium cromoglycate. It is well established that sodium cromoglycate protects against antigen challenge by inhibiting the release of chemical mediators from mast cells. It also inhibits exerciseinduced bronchoconstriction and has bronchodilator properties. ${ }^{1}$ Ketotifen has a similar capacity to inhibit the release of chemical mediators from mast cells. ${ }^{2}$ Its clinical effectiveness is still uncertain. ${ }^{34}$

\section{Patients, methods, and results}

Twenty-three children with a clinical history of asthma and a value on the Jones lability index greater than $20 \%$ were examined. The decrease in peak expiratory flow rate (PEFR) below the resting value was examined and remeasured on another day after the child had been given $20 \mathrm{mg}$ sodium cromoglycate solution via a Wright nebuliser and mains-driven compressor (Aerosol Products Ltd) 15 minutes before running. On a third day the test was repeated with $20 \mathrm{mg}$ sodium cromoglycate powder given 15 minutes before exercise. It was repeated on a fourth day after the patient had received three days' treatment with ketotifen ( $1 \mathrm{mg}$ twice a day by mouth). The last dose was given two hours before the test. The percentage fall index ((PEFR at rest-PEFR after exercise/PEFR at rest $) \times 100$ ) was measured in each case.

Sodium cromoglycate solution was the most effective inhibitor and reduced the percentage fall index to a mean of $12 \%$ (see table). Sodium cromoglycate powder was less effective, and ketotifen was ineffective. The degree of inhibition varied considerably. In 14 of the children given sodium cromoglycate solution inhibition was virtually complete (a percentage fall of less than 10), whereas only three showed this level of inhibition in response to sodium cromoglycate powder and one to ketotifen.

Action of sodium cromoglycate and ketotifen in inhibiting exercise-induced bronchoconstriction in 23 asthmatic children

\begin{tabular}{|c|c|c|c|c|}
\hline & \multirow{2}{*}{ Control } & \multicolumn{2}{|c|}{ Sodium cromoglycate } & \multirow{2}{*}{ Ketotifen } \\
\hline & & Solution & Powder & \\
\hline $\begin{array}{l}\text { Mean fall ( } \pm \text { 1 SD) in peak } \\
\text { expiratory flow rate }(1 / \mathrm{min}) \\
\text { Mean \% fall index }( \pm 1 \text { SD })\end{array}$ & $\begin{array}{r}122 \pm 37 \\
43 \pm 13\end{array}$ & $\begin{array}{l}37 \pm 36 \\
12 \pm 11\end{array}$ & $\begin{array}{l}69 \pm 44 \\
25 \pm 15\end{array}$ & $\begin{array}{r}118 \pm 76 \\
41 \pm 24\end{array}$ \\
\hline
\end{tabular}

Control $v$ cromoglycate solution: $\mathrm{p}<0.0005$; control $v$ cromoglycate powder: $\mathrm{p}<0.0005$; control $v$ ketotifen: $\mathrm{p}>0.1$; cromoglycate solution $v$ ketotifen: $\mathrm{p}<0.0005$ ketotifen : $\mathrm{p}=0.003$.

\section{Comment}

The results showed a clear difference between ketotifen and sodium cromoglycate. Both are known to protect against antigen challenge, but only cromoglycate prevents exercise-induced bronchoconstriction. In the case of cromoglycate the solution was more effective than the powder, as previously shown. ${ }^{1}$ Ketotifen may have proved ineffective against exercise-induced bronchoconstriction because it takes longer than three days to achieve its peak effect or because the dose was inadequate. These points may need further assessment, but higher doses would have to be considered in relation to the incidence of known side effects, in particular, drowsiness.

Sodium cromoglycate has been shown to have two distinct actions, one as an inhibitor of chemical mediator release from mast cells, and the other as a bronchodilator and inhibitor of exercise-induced bronchoconstriction, possibly due to more direct action on the bronchial muscle cells. ${ }^{1}$ It is understandable that drugs that inhibit antigen challenge are likely to help the asthmatic. In this respect ketotifen and cromoglycate are effective, although relative potency will need further assessment. The capacity to inhibit exercise-induced bronchoconstriction is perhaps less obviously related to the clinical effectiveness of a drug. There is plenty of evidence, however, that the degree of bronchial lability of an individual is a good indicator of pathophysiological state. ${ }^{5}$ Two drug actions are probably needed-protection against antigen challenge and action to induce bronchodilatation and inhibit exercise-induced bronchoconstriction. Ketotifen and sodium cromoglycate both possess the first, but only sodium cromoglycate possesses the second action.

This work was supported by grants from the Intensive Care Fund, Alder Hey Children's Hospital, and Fison's Ltd.

1 Chung JTN, Jones RS. Bronchodilator effect of sodium cromoglycate and its clinical implications. Br Med $\mathcal{F} 1979$;ii:1033-4.

2 Martin U, Roemer E. Ketotifen: a histamine release inhibitor. Monogr Allergy 1977;12:145.

${ }^{3}$ Craps L, Greenwood C, Radielovic P. Clinical investigation of agents with prophylactic antiallergic effects in bronchial asthma. Clin Allergy 1978; 8:373.

4 Dyson AJ, Mackay AD. Ketotifen in adult asthma. $\mathrm{Br}$ Med $\mathcal{F} 1980$;280: 360.

5 Jones RS. Assessment of respiratory function in the asthmatic child. Br Med f 1966;ii:972.

(Accepted 1 October 1980)

Respiratory Unit, Alder Hey Children's Hospital and University Department of Child Health, Liverpool L12 2AP

J D KENNEDY, MB, DCH, research assistant (present address: Leicester Royal Infirmary)

F HASHAM, MRCP, DCH, research assistant

M J D CLAY, technician in respiratory physiology

R S JONES, MD, FRCP, consultant paediatrician and director of studies in paediatric science

\section{Overdose with ibuprofen causing unconsciousness and hypotension}

Ibuprofen was introduced into Britain in 1967, and there have been no reported cases of overdosage. We report such a case, which resulted in depressed consciousness and hypotension.

\section{Case report}

A 70-year-old man presented one hour after ingesting about $30400-\mathrm{mg}$ tablets of ibuprofen. Blood was taken for ibuprofen estimation and gastric lavage performed. His consciousness then deteriorated rapidly and he responded only to painful stimuli. There were no localising neurological signs, reflexes were symmetrical, and plantar responses were flexor. Blood pressure fell from $120 / 80$ to $80 / 60 \mathrm{~mm} \mathrm{Hg}$ but central venous pressure remained constant at $6 \mathrm{~cm} \mathrm{H} \mathrm{H}_{2} \mathrm{O}$. Examination of the abdomen and respiratory system showed nothing abnormal. He was treated with an infusion of dopamine $2 \mu \mathrm{g} / \mathrm{kg} / \mathrm{min}$ and his blood pressure rose to $110 / 70 \mathrm{~mm} \mathrm{Hg}$, but five hours later when the dopamine was discontinued it fell to $70 / 50 \mathrm{~mm} \mathrm{Hg}$. Dopamine was restarted at $2 \mu \mathrm{g} / \mathrm{kg} / \mathrm{min}$ and continued for a further 13 hours. By that time he had become fully conscious and blood pressure remained at $120 / 80 \mathrm{~mm} \mathrm{Hg}$ when the dopamine was discontinued.

The initial serum concentration of ibuprofen was $840 \mathrm{mg} / 1$ (therapeutic range $20-30 \mathrm{mg} / \mathrm{l})$, blood sugar $6.8 \mathrm{mmol} / \mathrm{l}(123 \mathrm{mg} / 100 \mathrm{ml}$ ), and calcium $2.5 \mathrm{mmol} / \mathrm{l}(9.8 \mathrm{mg} / 100 \mathrm{ml})$. A serum drug screen performed by the poisons unit, New Cross Hospital, on a sample taken three hours after admission identified only ibuprofen $220 \mathrm{mg} / \mathrm{l}$, diazepam $0 / 47 \mathrm{mg} / \mathrm{l}$, and nordiazepam (desmethyldiazepam) $0.07 \mathrm{mg} / 1$ (less than the normal therapeutic range) Faecal occult blood was not detected and serial electrocardiograms and cardiac enzyme activities were normal.

\section{Comment}

Many patients with rheumatological disorders are treated with ibuprofen. From this case apparently a depressed level of consciousness and hypotension may result soon after ingestion of more than the maximum dose. Side effects when taking the normal dose include headache, amblyopia, and lightheadedness but there is no record of depressed consciousness. The findings of Adams et al in animals 
suggest that ibuprofen has minor effects on the cardiovascular system, but our experience points to the contrary.

Care should be exercised in prescribing ibuprofen to people who are liable to take overdoses.

We thank Mr L Higginbotham, department of biochemistry, Royal Manchester Children's Hospital, and the poisons unit, New Cross Hospital, for their analyses, and Boots Company Limited for their help.

${ }^{1}$ Adams SS, Bough RG, Cliffe EE, et al. Absorption and distribution and toxicity of ibuprofen. Toxicol Appl Pharmacol 1969;15:310-30.

(Accepted 22 September 1980)

Department of Medicine, Hope Hospital, Salford M6 8HD

DIANA P HUNT, MB, CHB, senior house officer

RICHARD J LEIGH, MB, MRCP, tutor in medicine

\section{Plasma exchange to control sweats and pruritus in malignant disease}

Pruritus and sweating attacks in malignant diseases such as the lymphomas are well recognised and disappear with successful treatment of the malignancy. Cimetidine, a potent histamine $\mathrm{H}_{2}$-receptor antagonist, controls these symptoms in Hodgkin's disease, ${ }^{1}$ but their pathogenesis is not explained. If pruritus and sweating were caused by metabolically active substances released into the plasma by the tumour such substances might be removed by plasma exchange. ${ }^{2}$ We have tested this idea and report our preliminary findings.

\section{Case reports}

Case 1-A 54-year-old woman had non-Hodgkin's lymphoma (diffuse poorly differentiated lymphocytic) diagnosed in October 1977. She had lef supraclavicular and epigastric masses and complained of general ill health and severe generalised itch. She initially responded well to cyclical administration of mustine hydrochloride, vinblastine, procarbazine, and prednisolone, with disappearance of the itch; but this and subsequent responses to chlorambucil, vinblastine, procarbazine, and prednisolone and then doxorubicin, bleomycin, vincristine, and dacarbazine were not maintained. In autumn 1979 she received palliative radiotherapy to an abdominal mass. General ill health, wasting, and intractable itch continued, the itch being unrelieved by cimetidine $800 \mathrm{mg}$ daily. A therapeutic trial of plasma exchange was conducted with a Hemonetics model 30 cell processor, with human pooled fresh-frozen plasma as replacement solution. On the first occasion 4.91 plasma was removed, and eight days later 4.3 1 . Itching disappeared after the first exchange and remained virtually absent for several weeks. No other treatment was given. She died two months after the plasma exchange.

Case 2-A 53-year-old man had a left nephrectomy for renal carcinoma in April 1979. Radiography showed numerous small discrete lung metastases and he was treated for four months with iphosphamide at three-week intervals, with no evidence of progression. Lung metastases then enlarged and tamoxifen was substituted but discontinued after only two months because of progressive disease. There was a painless mass in the nephrectomy scar $5 \times 4.5 \mathrm{~cm}$. His only notable symptom was severe night sweats. Plasma exchange performed as in case 1 (3.4 1 plasma removed initially) resulted in an immediate and sustained reduction in the number and severity of night sweats, with only light sweating occurring not more than twice weekly. Four further plasma exchanges $(3 \cdot 3,4 \cdot 6,4 \cdot 0$, and 3.61$)$ were conducted over the next nine weeks. The mass in the nephrectomy scar regressed to $4 \times 3 \mathrm{~cm}$ but the lung metastases continued to enlarge. No other treatment was given. Medroxyprogesterone acetate $100 \mathrm{mg}$ thrice daily was prescribed two weeks after the fifth plasma exchange, though the light sweating at night had not increased beyond twice a week.

\section{Comment}

From these observations plasma exchange may control severe itching or sweating in advanced malignancy when drugs have failed to do so. This apparently confirms the suggestion that itching and sweating are caused by circulating factors produced by the tumour or as a host response, though it does not exclude the possible effect of an active blocking factor added by the fresh-frozen plasma. The results justify further investigation of plasma exchange to elucidate the mechanisms producing the symptoms. It may be possible to isolate circulating factors in extracorporeal blood with in-series selective affinity columns ${ }^{3}$ and use dialysis of exchanged plasma to establish their nature and physical characteristics.

J $M$ Trotter was in receipt of a grant from Roussel Laboratories Limited. We thank Dr T Habeshaw for referring one of the patients.

Aymard JP, Lederlin P, Witz F. Cimetidine for pruritus in Hodgkin's disease. $\mathrm{Br}$ Med $\mathcal{f} 1980 ; 280: 151-2$.

2 Trotter JM, Shaw D, Carlyle E, Shephard J, Calman KC. Nutritional aspects of plasma exchange in cancer patients. In: Serrou B, ed. Immune complexes and plasma exchange in cancer patients. Amsterdam: Elsevier North Holland (in press).

3 Terman DS, Yamamoto T, Mattioli M. Extensive necrosis of spontaneous canine mammary adenocarcinoma after extracorporeal perfusion over Staphylococcus aureus cowans I. $\mathcal{F}$ Immunol 1980, 124:795-805.

(Accepted 22 September 1980)

University Department of Pharmacology and Therapeutics, Ninewells Hospital and Medical School, Dundee DD1 9SY

D SHAW, MD, MRCP, lecturer in therapeutics

University Department of Clinical Oncology, Gartnaval General Hospital, Glasgow G12 9LY

J M TROTTER, MB, FRACP, research fellow

K C CALMAN, MD, PHD, professor of clinical oncology, Cancer Research Campaign

\section{Oxprenolol and retroperitoneal fibrosis}

Retroperitoneal fibrosis is a fairly rare cause of impaired renal function. Methysergide taken for migrain ${ }^{1}$ and also abuse of analgesic drugs have been implicated in some earlier cases. Recently it has been reported in patients who had taken the beta-blocker atenolol. ${ }^{2}{ }^{3} \mathrm{We}$ report retroperitoneal fibrosis occurring in a patient who had been taking oxprenolol for five years.

\section{Case report}

In June 1979 a 53-year-old male charge nurse was referred by his general practitioner because of a persistently raised blood urea concentration of 23.0 $\mathrm{mmol} / 1(140 \mathrm{mg} / 100 \mathrm{ml})$, mild anaemia (haemoglobin $10 \cdot 1 \mathrm{~g} / \mathrm{dl}$ ), and raised erythrocyte sedimentation rate (ESR) at $62 \mathrm{~mm}$ in $1 \mathrm{~h}$, Westergren. He had suffered from angina pectoris for four years and mild ankle swelling in the preceding 6 months. In 1974 he had been started on oxprenolol $80 \mathrm{mg}$ twice daily for hypertension. In 1978 oxprenolol had been changed to Slow Trasicor $160 \mathrm{mg}$ once daily, and for about the past six months he had also been taking Adalat $10 \mathrm{mg}$ three times daily and Hygroton $\mathrm{K} 50 \mathrm{mg}$ once daily.

When referred to us his blood urea was $20.0 \mathrm{mmol} / 1(120 \mathrm{mg} / 100 \mathrm{ml})$, haemoglobin $10.7 \mathrm{~g} / \mathrm{dl}$, serum creatinine $340 \mu \mathrm{mol} / 1(3.4 \mathrm{mg} / 100 \mathrm{ml})$, and his creatinine clearance was $31 \mathrm{ml} / \mathrm{min}$. He was admitted for investigation. Clinical examination was unremarkable. His blood pressure was well controlled at $120 / 70 \mathrm{~mm} \mathrm{Hg}$ and his pulse regular at $72 / \mathrm{min}$. His ESR was $114 \mathrm{~mm}$ in $1 \mathrm{~h}$. A high-dose intravenous pyelogram showed poor excretion of contrast medium by both kidneys, a large left-sided hydronephrosis, and the ureters displaced medially. Retroperitoneal fibrosis was diagnosed and confirmed at operation, when dense fibrous tissue was found extending retroperitoneally down into the pelvis and around both ureters. Multiple specimens of tissue were taken for biopsy and bilateral ureterolysis performed. Biopsy specimens showed dense collagenous, relatively acellular fibrous tissue with no evidence of vasculitis and no malignant cells. The appearances were typical of retroperitoneal fibrosis. Postoperative recovery was uneventful and he was discharged well without a hypotensive drug. At follow-up two months later his blood urea concentration had fallen to $11.0 \mathrm{mmol} / 1$ (66 $\mathrm{mg} / 100 \mathrm{ml})$ and serum creatinine concentration to $215 \mu \mathrm{mol} / 1(2 \cdot 15 \mathrm{mg} / 100$ $\mathrm{ml}$ ), and his creatinine clearance had increased to $42 \mathrm{ml} / \mathrm{min}$. Clinically the only abnormal finding was a blood pressure of $170 / 100 \mathrm{~mm} \mathrm{Hg}$. He was started on a thiazide diuretic. The only other drug he has taken since is glyceryl trinitrate for angina pectoris.

\section{Comment}

The histological appearance of retroperitoneal fibrosis occurring in association with ingestion of methysergide does not differ from that not known to be associated with drug ingestion. The appearance of 